\title{
Essays on drivers and long-term impact of migration
}

Citation for published version (APA):

Özer, M. N. (2020). Essays on drivers and long-term impact of migration. [Doctoral Thesis, Maastricht University]. ROA. https://doi.org/10.26481/dis.20201104mo

Document status and date:

Published: 01/01/2020

DOI:

10.26481/dis.20201104mo

Document Version:

Publisher's PDF, also known as Version of record

\section{Please check the document version of this publication:}

- A submitted manuscript is the version of the article upon submission and before peer-review. There can be important differences between the submitted version and the official published version of record.

People interested in the research are advised to contact the author for the final version of the publication, or visit the DOI to the publisher's website.

- The final author version and the galley proof are versions of the publication after peer review.

- The final published version features the final layout of the paper including the volume, issue and page numbers.

Link to publication

\footnotetext{
General rights rights.

- You may freely distribute the URL identifying the publication in the public portal. please follow below link for the End User Agreement:

www.umlib.nl/taverne-license

Take down policy

If you believe that this document breaches copyright please contact us at:

repository@maastrichtuniversity.nl

providing details and we will investigate your claim.
}

Copyright and moral rights for the publications made accessible in the public portal are retained by the authors and/or other copyright owners and it is a condition of accessing publications that users recognise and abide by the legal requirements associated with these

- Users may download and print one copy of any publication from the public portal for the purpose of private study or research.

- You may not further distribute the material or use it for any profit-making activity or commercial gain

If the publication is distributed under the terms of Article $25 \mathrm{fa}$ of the Dutch Copyright Act, indicated by the "Taverne" license above, 


\section{Nederlandse samenvatting}

In de OESO-landen is het aantal hoogopgeleide immigranten tussen 1990 en 2010 met $130 \%$ gestegen (Kerr et al., 2016). Ook is het aantal internationale studenten dat in het hoger onderwijs is ingeschreven tussen 2008 en 2018 met $39 \%$ gestegen (OECD, 2019). De toenemende migranten instroom van hoogopgeleide werknemers en internationale studenten is mede het gevolg van het migratiebeleid ten aanzien van 'kenniswerkers' dat gericht is op het oplossen van tekorten aan gekwalificeerd personeel op de arbeidsmarkt (OECD, 2018). Vooral vanwege de sterke toename van het aantal vluchtelingen in het afgelopen decennium blijft migratie een onderwerp van publiek debat. Een van de kernpunten van het publieke debat over migranten is de integratie van laagopgeleide immigranten en vluchtelingen, aangezien zelfs de tweede en derde generaties achterblijven bij hun autochtone leeftijdsgenoten, zowel wat betreft hun opleidingsniveau als hun succes op de arbeidsmarkt (bijvoorbeeld Algan et al., 20Io).

Internationale migratie markeert een belangrijke wending in het leven van individuen, die voortvloeit uit een reeks opeenvolgende beslissingen over de vraag of ze willen migreren, naar welk land ze willen gaan en of ze in het gastland willen blijven, naar hun land van oorsprong willen terugkeren of naar een ander land willen migreren. Deze dissertatie is bedoeld om licht te werpen op de migratiebeslissingen en de sociaaleconomische positie van migranten. In drie studies van dit proefschrift richten we ons op de migratiebeslissing (hoofdstuk 2 en 3) en de beslissing om al dan niet in het migratieland te blijven (hoofdstuk 4) van hoogopgeleide individuen. In de vierde studie richten we ons op de toekomstige arbeidsmarktuitkomsten van migranten van de tweede generatie (hoofdstuk 5). In de eerste drie studies gaan we in op de impact van risicovoorkeuren, persoonlijkheidskenmerken en de culturele afstand tussen landen bij het verklaren van de migratiebeslissingen van individuen (migratiefase), en de beslissing van migranten om te blijven (blijffase). In de vierde studie richten we ons op de intergenerationele uitkomsten van migratie in de integratiefase.

Meer specifiek beoogt het proefschrift een antwoord te geven op vier vragen die verband houden met migratie:

I. Zijn de beslissingen van individuen om te migreren naar landen die cultureel gezien ver van hun land van herkomst verwijderd zijn, gerelateerd aan hun risicobereidheid? (Migratiefase - hoofdstuk 2) 
2. Zijn de intenties van individuen om te migreren naar landen die cultureel gezien ver van hun thuisland verwijderd zijn, gerelateerd aan hun persoonlijkheidskenmerken? (Migratiefase - hoofdstuk 3)

3. Verschillen de voorkeuren van internationale studenten in bèta/technische vakgebieden van die van autochtone studenten en zijn deze verschillen toe te schrijven aan culturele verschillen tussen de landen waar internationale studenten zijn geboren en waar zij studeren? (Blijffase - hoofdstuk 4)

4. Heeft de kwaliteit van de buurten waar immigranten van de tweede generatie zijn geboren en opgegroeid invloed op hun werkgelegenheid en inkomen op de lange termijn? (Integratiefase - hoofdstuk 5)

Hoofdstuk 2 onderzoekt het verband tussen de risicobereidheid van pas afgestudeerden, hun migratiestatus en de culturele afstand tussen het land waar ze zijn geboren en het land waarnaar ze zijn geëmigreerd. We richten ons hier op hoogopgeleide afgestudeerden, die veel gevraagd zijn op de internationale arbeidsmarkt. We maken gebruik van gegevens van Nederlandse hbo- en wo-afgestudeerden uit het ROA Schoolverlatersonderzoek, met informatie over het land waar deze afgestudeerden kort na hun afstuderen werken en over hun risicovoorkeuren. We ontwikkelen een culturele afstandsindex op basis van de nationale cultuurdimensies van Hofstede (200I). Deze index kwantificeert de culturele afstand tussen Nederland en de landen waar afgestudeerden voor hun werk naartoe zijn geëmigreerd. Het onderzoek laat zien dat afgestudeerden die meer risicobereidheid zijn vaker in het buitenland gaan werken. Een hogere risicobereidheid hangt ook samen met een toename van de culturele afstand tussen het land van herkomst en het land waar afgestudeerdenzijn gaan werken.

Hoofdstuk 3 breidt het toepassingsgebied van hoofdstuk 2 uit door de associatie te analyseren tussen de persoonlijkheidskenmerken van individuen en hun intentie om te migreren naar landen die cultureel gezien ver van hun geboorteland verwijderd zijn. Ook dit onderzoek is gericht op hooggekwalificeerde arbeidskrachten. We gebruiken gegevens van Duitse universiteitsstudenten uit de Fachkraft-enquête die vragen bevat over de intentie van studenten om na hun afstuderen voor hun werk naar het buitenland te emigreren, de landen die ze beschouwen als potentiële bestemmingen en hun persoonlijkheid gemeten aan de hand van de Big 5-persoonskenmerken (extraversie, aangenaamheid, gewetensvolheid, emotionele stabiliteit en openheid) (Goldberg et al., 2006). We gebruiken in dit hoofdstuk de in hoofdstuk 2 ontwikkeld culturele afstandsindex op basis van de nationale cultuurdimensies van Hofstede (200I). Uit het 
onderzoek blijkt dat degenen die meer extravert zijn en openstaan voor nieuwe ervaringen sterkere intenties hebben om te migreren. Daarentegen zijn degenen die vriendelijker, meer nauwgezet en emotioneel stabieler zijn minder geneigd om te emigreren. Bovendien hebben openheid en extraversie een negatieve relatie met de bereidheid om naar landen te emigreren die cultureel gezien sterk verschillen. Door taalafstand als alternatieve maatstaf voor culturele afstand te gebruiken, laten we zien dat extroverte en gewetensvolle individuen aanzienlijk minder vaak de voorkeur geven aan landen waar Duits en Engels geen officiële talen zijn, terwijl de studenten die hoog scoren op vriendelijkheid deze landen eerder als alternatieve bestemmingen zullen beschouwen. De geringere bereidheid van extroverte personen om naar landen met een grote culturele afstand te emigreren lijkt verband te houden met de taalverschillen die de totstandkoming van sociale relaties, die door extroverte personen als belangrijk worden ervaren, kunnen bemoeilijken.

In hoofdstuk 4 wordt onderzocht of internationale studenten die aan Nederlandse universiteiten studeren worden aangetrokken door andere functiekenmerken dan autochtone studenten, en of deze verschillende voorkeuren toe te schrijven zijn aan de culturele verschillen tussen Nederland en de landen waar internationale studenten zijn geboren en getogen. Voor dit hoofdstuk gebruiken we gegevens uit een stated-choice-experiment dat is uitgevoerd onder masterstudenten van de twee grootste Nederlandse technische universiteiten in Delft en Eindhoven. Dit stated-choice-experiment is gericht op het meten van de voorkeuren van studenten voor functiekenmerken die belangrijk zijn voor het goed kunnen werken in een 'high performance workplace': autonomie op het werk en teamwerk. Met behulp van de nationale cultuurdimensies van Hofstede (200I) om de culturele afstand van internationale studenten tot Nederland te kwantificeren, onderzoeken we de voorkeuren van internationale en Nederlandse studenten voor banen waarin autonomie en teamwerk vereist zijn. De resultaten van dit hoofdstuk laten zien dat de bèta/technische internationale MSc-studenten in Nederland een geringere voorkeur hebben voor autonomie en teamwerk dan Nederlandse studenten. Deze verschillende voorkeuren hangen samen met de culturele afstand tussen het geboorteland van internationale studenten en Nederland. Studenten uit culturen die gekenmerkt worden door een grotere machtsafstand en een lager individualisme geven minder snel de voorkeur aan functieprofielen met een hogere mate van autonomie, terwijl studenten uit culturen die gekenmerkt worden door een hogere mate van mannelijkheid minder snel de voorkeur geven aan het werken in teamverband. 
In hoofdstuk 5 wordt onderzocht of de kwaliteit van de buurten waarin tweedegeneratie immigranten zijn geboren en opgegroeid van invloed is op hun latere prestaties op de arbeidsmarkt. Voor dit onderzoek maak ik gebruik van de werkgelegenheids- en inkomensgegevens van het CBS om de effecten van de kwaliteit van de buurt op de economische integratie op lange termijn te analyseren van de tweede-generatie Molukse immigranten die in Nederland in kampen zijn geboren nadat hun familie in 195I uit Indonesië werd weggehaald vanwege de politieke onrust in die tijd. Daarbij wordt de toevallige toewijzing van Molukse gezinnen aan een bepaald kamp benut om de causale impact van kampen woonkenmerken op de arbeidskansen en het inkomen van hun kinderen op latere leeftijd in kaart te brengen. De kampen verschilden van elkaar in termen van de lokatie, voorzieningen en grootte. Meer specifiek is daarbij gekeken naar de afstand tot een kerk als proxy voor de afstand tot de dichtsbijzijnde lokale gemeenschap, de potentiële toegang tot de lokale arbeidsmarkt, de beschikbaarheid van schoolvoorzieningen en het aantal Molukkers dat in het kamp woont. De uitkomsten van deze studie laten zien dat het geboren worden in een kamp dat arbeidskansen in de nabije omgeving bood, een positief effect heeft gehad op de kans dat de vrouwen die in die kamp geboren zijn werk hebben als ze 50 en 60 jaar oud zijn. De werkgelegenheidskansen van mannen die zijn geboren in kampen met arbeidsmogelijkheden in de buurt verschillen niet significant van die van mannen die zijn geboren in kampen zonder arbeidsmogelijkheden in de buurt. Het feit dat zij in kampen met arbeidskansen in de buurt worden geboren, verbetert echter wel de duurzaamheid van de arbeidsmarktparticipatie voor mannen in de jaren voor hun pensionering. 